\title{
A Cross-Cultural Analysis of Transnational Marriage: Franco-Indonesian Marriage Case
}

\author{
T. I. Hardini \\ Universitas Pendidikan Indonesia
}

\begin{abstract}
Due to the development of communication technology, IT, and transportation, transnational marriage is very possible. However, this kind of marriage can result in conflict of interest due to the cultural divergence background. If this issue was not overcome, it may lead to a communication failure between two cultures. This research was conducted to discover any cultural communication issues that occurred in a couple where the husband is French and the wife is Indonesian. This research was conducted by using descriptive method and qualitative approach and the data collection were carried on by using direct observation and interview with the research's participants. The result was presented descriptively, and it is showed that all of the communication issues that were caused by stereotype, prejudice and inclination to judge had been generalized by others citizen as well. It was found that French secularity, or Laïcité may become a very complicated issues for Indonesian spouse whereas in Indonesia a religion matter is a very fundamental course that has been taught since elementary level. Another example was one of Javanese cultureSungkeman- that actually symbolizes the evidence of submission may not suitable with the value of égalité that is hold by French citizen. Even a simple motion such as body language could rise an issue as well; a haptic communication that was very common for French citizen may cause cultural shock for Indonesian spouse. It was a very crucial issues since it might influence the spouse on a daily life, and cause a conflict. In addition, a language barrier between a marriage couples may cause misinterpretation or a problem.
\end{abstract}

Keywords: cross-culture, franco-indonesian marriage, marital conflicts, laïcité, haptic communication.

\section{INTRODUCTION}

Every human being experiences many changes, and conducting their development task starting from infancy, childhood, teenage, adult, and elderly till their death. According to Hurlock (2000), the early adulthood phase is the longest that every human being has ever experienced. Additionally, on this phase each individual has their responsibility to complete the development of life by finding a "mate" that will lead them into a matrimony bond (Hurlock).

Marriage has been known socially as a relationship of a consent adult between a man and a woman that involve sexual activity, reproduction, the control and custody of children, and also learning the role of being a husband and wife (Duvall \& Miller, 1985). It is also understood that marriage is a bond that involves intimacy, friendship, love, sexual satisfaction and a change toward maturity (Papalia \& Olds, 2008). It is found that the inclination on finding a perfect spouse started from an identical trait between a couple (Sear, et al., 1991), whether it is faith, hobby, character, mindset or even culture values. The term is called matching principle however, with the development of technology today, it allow for someone to communicate from distance that not only allow it to interact but also may create the possibility of transnational marriage.

After the World War II, the transnational marriage has been scattered all over the world due to the individual encounter from every nation. On colonization era, this may happen due to the soldiers encounter with local woman. Nowadays, transnational marriage may occur in a very common places such as on meeting, at workplace, school, organization, social activity, and many other places.

Intercultural marriage with a difference nationality can be categorized as a transnational marriage. This phenomenon has been a very common occurrence due to the development communication system that allow every individual to recognize others culture. This has been a very interesting topic especially the "West meet East" cases. This may happen because there is an idea that "East Women are Hot" (Kompas, Kolom Kita, 14 Juni 2008). Our world is shrinking and people can freely moving around outside their home country. It is very common that some Australian men intentionally come to Philippine merely to find a wife. Many Indonesian women are wooed by many men from USA, UK, and many western men. Young women in Indonesia more and more turn to western men such as France, England, Germany, or USA by using international dating agency.

Aliansi Pelangi Antar Bangsa (Rainbow Alliance between Nations or APAB) is an organization that suggesting citizenship rules on 2005, and it is implemented at 2006 on Indonesian Citizenship Rule no. 12. According to them, on 2014 there are more than 4500 Indonesian women that married foreigners, and it is believed that this trend will keep increasing yearly although the recent data has not been published yet. It is also found that Indonesian women have a great interest in marrying foreigners.

\section{FACTORS IN THE TRANSNATIONAL MARRiage}

An Interest toward foreign men usually indicated by economic factor which Indonesian women thought that foreign men have a stable standard of living (Erriyadi, 2007). 
Besides, Holilah (2005) showed that Indonesian women believe that by marrying foreign men, especially those from the west will be able to "fix" the gene up front.

Beyond all of the motives, it is love that becomes the most crucial reason why Indonesian women choose foreign men, especially the western men. According to Roediger et al., (1993), love is a form of emotion that is very important for every human being thus everyone has experienced falling in love and create an intimacy bond thru marriage.

On the contrary, on this occasion it is also found that foreign men -in this case is the French- also have specific reason why they would likely to marry Indonesian women to be their wives'.

From an interview result with two foreign men, it is discovered that those men married Indonesian women because they have a view that Indonesian women are polite, motherly, soft, gentle \& kind, and respecting the husband thus it fits the wife's criteria compare to the European's women which are independent. In general, intercultural marriage has become more and more common in Indonesia and it somehow become a normal phenomenon in our society (McDermott \& Maretzki, 1977)

According to Degenova (2008) a relationship before and after marriage are two different things that cannot be compared. A lot of new things will figured by each individual and they will need to accept their spouse as it is. With a different culture of background, each of individual will face a difference view of value, character, believe, prejudice, stereotype and many more (Matsumoto, D. \& Juang, L., 1985). The couple may have introduced a new culture toward each other (Duvall, 1985) however, it cannot be denied that this difference will become a root of problems of intercultural marriage.

\section{RESEARCH METHODOLOGY}

This research had been conducted by using qualitative method. Furthermore, snow balling sampling was used to collect the sample to Indonesian citizen that married with French citizen and reside in France as well. The data was gathered by using interviews and direct observation with the research participants.

\section{A Cross-CUltural ANALYSIS OF TRANSNATIONAL MARRIAGE: FRANCO-INDONESIAN MARRIAGE BASED ON SOCIAL CULTURE ELEMENTS.}

\section{A. Belief}

In anthropology, religion is one from seven social culture elements that includes religion and belief system. Religion can be used as a base on how human act and conduct. On belief system, almost $90 \%$ of Indonesian population are Islam, while France are $85 \%$ Catholic. This difference becomes a very great obstacle in marriage process as Indonesian women prefer to do a marriage in Islamic way.
In majority, French citizens think that Laïcite is a true protector of religion and personal rights. Laïcité or Laicism is not a doctrine that is believed or not believed by someone. People can be any kind of believers and yet still be a laisis. It is a philosophy concept, where people do not question a freedom of belief and yet it still allow them to live together in harmony. Laicism is a priori construction that allows everyone to shout their opinions where it is limited by public rights that push and create certain rules. An individual does not to be a member of certain community to enjoy the freedom of speech as the public rights is not affected by his or her devotion toward certain belief or not. This principle is implanted in France to raise an awareness of tolerance.

Laicism is not against the religion however, it rejects the idea of religion's demand as a law foundation or politic membership. The opposite of Laicism is "Civil of Religion" where the constitution of religion is converted into civil law or the other way around. An anti-religion attitude will limit the freedom of belief into a personal sector which is clearly against the laicism: freedom of expressions. In FrancoIndonesian marriage, a debate usually arise on how to foster the children as this aspect will affect the children differently.

\section{B. Value}

Ethnocentrism is a concept where individuals value other's culture as inferior against their culture (Rogers \& Steinffat, 1999). Without looking the individual involves and how, ethnocentrism will always be a road block of effective cultural communication. It is needed to be known that the concept is being grasped by every individual unconsciously but expressed in conscious way thus every act should be watched thoroughly.

Stereotype is a generalisation towards ceratin community that is very downgrading reality (Rogers \& Steinffat, 1999). This attitude is usually shown where people someone judges certain person based on the ethnicity and follow by personal opinion. Therefore, when there is an intercultural contact, both participants will represent their ethnic. The problem though if each participant only focuses on the negative stereotypes hence the original perception remain unchanged.

Prejudice is a stiff action towards certain community based on belief and a wrong pre-conception that is followed by misjudging and misunderstanding (Rogers \& Steinffat, 1999). Because of that, an individual will create a barricade against other, and furthermore it will affect emotionally if the prejudice is contradictive. This is usually expressed by communication, and the worst case will lead someone to close their mind against the truth.

It can be concluded that stereotype can be expressed by belief, while attitude is a form of prejudice's expression. In intercultural communication, stereotype and prejudice play a very important role. Granted that both aspects can be positive or negative yet it may change one's perspective toward someone.

In practical, those three elements can be very visible among spouses of intercultural marriage however, by 
knowing this earlier each couple can be more supportive and overcome any obstacle together. From an interview, "A" stated that she have a principle with his husband to keep supporting and believing that this issues won't be a matter. By changing their perspective, a cultural issues won't become a problem. However, "A" also stated that one her relative was trying to implement this principle but eventually that couple was separated anyway due to the cultural difference.

\section{Attitude/Behavior}

A research found that there is significance difference in individual collective of culture such as dining etiquette with family. Individual collective of culture encourage children to be independent from a young age. Adaptability between a couples it must necessary be done to achieve final agreement in their marriage (Degenova, 2008). This statement is also agreed by Inman et al (2011) where it is a conflict in marriage can be issued due to the difference of agreement that is oriented to the family value. Adaptability of marriage can be done by modifying, accepting, or changing one's view towards another value for maximum satisfaction in relationship (Degenova). While changing of attitude is not always right however, it is the best way to achieve the maximum satisfaction on relationship. Degenova also stated that this changes however is a dynamic process and always continuously done throughout the age of marriage. By adapting of this element, it may avoid a conflict and on the same time resolve a conflict in marriage (Hurlock, 2008). For the happiness of marriage, many adaptation can be done such as financial, sexual, and agreement between the in-laws (Hurlock).

It is true that every marriage needs adaptation. Adaption can be done by learning, and understanding their spouse, and followed by the needs. It won't be so much hardship especially for those who have the same value. Financial adaptation and family adaptation usually comes after a couple understand and satisfy with their needs. According to Hurlock (2000), the first and second year of marriage is the hardest part for adaptation. Usually this phase occur especially after honeymoon, thus adaptability is important. Failing to do so may face a failure in marriage (Hurlock). Adaptation and responsibility is a key toward a successful marriage, that later will influence in decision making, avoidance of prejudice, and anxiety of marriage. Women that get married with foreign men usually need a good adaptation because of the many difference in value, belief and attitude. According to Lerrigo (2005), a difference in culture, language, value mind set and religion are always the source of troubles in marriage.

\section{Worldview}

Asian women have a different self assumption of the Western women, according to research conducted on women in 12 Asian countries. Asian women considered themselves voluptuous, wild, rude, naughty, passionate, strong and even likes to tease, they also do not feel miserable or depressed.

However, the general perception of the West about Asian women are petite, gentle, graceful, beautiful, affectionate, obedient and trustworthy. There is also a bad presumption, that Asian women easily obtained, even "bought" for urgency of economic necessity, or as Filipino woman who seemed all ladies bar and hostesses, when in fact not a few Filipino women have higher education, or an Indonesian woman who is able to harmonize the circumstances surrounding, Hong Kong and Chinese women are astute or "ling jing". Indian woman, though dressed in "sari" can do anything. Japanese women, obedient and very loyal, and women Singapore positive and active (Kompas, Column Kita, June 14, 2008).

Meanwhile, the foreign men are generally imaged as rich, dashing, and handsome. However, it all is a view that is not necessarily true. Only glimpse of stigma against Western culture is being progressed.

Cases that have appeared, as mentioned above, is the "clash of characters" of couples of different cultures. British male character, for example, and women of Asia (including Indonesia) is very different from the character of British women. Samovar (2010) says that European women are more independent than Asian women, so this if Western men married to Asian women, she always participated at the will of western man. Cases that often arises is the migration of Asian women to her country, which of course raises a cultural shock for the Asian women.

In the process of international communication, the elements that determine the work and function in an integrated manner together as components, because each of the interdependent and interrelated. But in the study, the elements are separated in order to be identified and reviewed one by one (Mulyana, 2001).

We all might see an object or the same social events and provide the same objective meaning, but the meaning is not impossible to be a different individual. For example, the Americans with Arab women agreed to declare a person based on physical form. But most likely both will have different opinions about how women in their social significance. Americans saw the value of equality between men and women, while the Arabs looked at women tend to emphasize women as housewives (Mulyana, 2004: 188).

Gudykunst et al (1996: 35) give the following example:

"Pay attention to the visit of a foreign-embracing culture that eye contact during communication is taboo in North America. When the stranger spoke to residents of North America by avoiding eye contact, then he will be considered hiding something or not telling the truth ".

\section{INTERCUltural COMMUNICATION OBSTACLES}

Cultural differences along with other differences in an individual (eg: an individual's personality, age, sex, and physical appearance) can contribute to the nature of the problems inherent in intercultural communication. According to Jandt (2001) there are three fundamental differences in the process of intercultural communication, namely:

\section{1) Language barrier}




\section{2) The difference in value and \\ 3) Differences in cultural behavior patterns.}

\section{CONCLUSION}

In a transnational marriage, when language and taste are different, conveying a hidden agenda will be a great difficulty. Cultural backgrounds often can not be spoken, but can only be felt. Mindset was formed many years is not easily conveyed to people of different cultures. Often this becomes the culprit frustration and disappointment in the marriage between nations.

In general, Indonesian women who married to French nationals experiencing various problems in marriage, such as language barriers, differences in values and differences in cultural behavior patterns. Transnational marriage problem can be understood because in each pair embracing different cultures. In the eastern culture (Indonesia) more impressive collective life are family and more based on the norms that exist in the environment, whereas in western culture is usually more impressive free life and individual. In other words, in a marriage like this has a collective familyindividualistic orientation. Differences in individualcollective cultural orientation in marriage between nations also have differences in terms of parenting. In the collective culture oriented to the extended family, where the children grew up not only of parents, but people who live together as grandparents who contribute to the care. In addition, children are also invited to learn to think that they are part of the group, while the individual culture based on the nuclear family (nuclear family), where children are taught to be independent from an early age (Hofstede, 2010).

There are many other issues that can be a source of conflict, such as lifestyle, food and diet, relationships with extended family, social life with friends, interpretation of body language / gestures, perception of authority figures, and moral standards. All it also occurs in the marriage of the nation, but the challenges become more severe in marriage between nations.

Some things to consider in transnational marriage Indonesia - France, namely:

Acknowledging differences and make it as an asset in a marriage, not a weakness.

Avoid prejudices about anything that could lead to conflict and heartache.

Communicate sensitive matters as soon as possible and need a strong will to accept the things that can not be understood at this time to be discussed in the future, when the mood of both parties is more stable.

Having a friend along an acceptable partner, as far as possible the couple well. It would be better if there are couples who married interference between nations as well. Social life and friendships are very important to support and strengthen marriage.

It takes a strong will to continue to enrich each other's culture continuously.
Necessary third party wise and neutral to help lower the emotions so that the ratio can work well.

Provide information to Asian women, especially Indonesian women married to foreigners (in this case France), to be able to understand the factors - what factors are most frequently performed or contribute greatly in marriage among nations, so as to assist them in adjusting wedding and achieve success home life.

Provide information to people who are not married on adjusting the marriage so that it can be input and will undergo a learning process for a wedding.

Provide information and advice to practitioners in marriage counseling, particularly regarding marriage adjustment on Indonesian women who marry a French man in dealing with marriage problems between nations.

\section{REFERENCES}

[1] DeGenova, M.K. Intimate Relationships, Marriages \& Families (Seventh Edition). New York: McGraw-Hill; 2008.

[2] Duvall, E \& Miller, C. M. Marriage and Family Development 6th ed. New York: Harper \& Row Publisher; 1985.

[3] Erriyadi. Kawin dengan Pria Asing, Artikel. Available FTP :http://www.geogle.com/kawinkontrak-com/2007/11/10.

[4] Gudykunst, W. B., Matsumoto, Y., Ting-Toomey, S., Nishida, T., Kim, K., \& Heyman, S. The influence of cultural individualismcollectivism, self-construals, and individual values on communication styles across cultures. Human Communication Research, 22 (4), 510$543 ; 1996$.

[5] Hofstede, Geert, Gert Jan Hofstede, Michael Minkov, Cultures and Organizations: Software of the Mind. 3rd Edition, McGraw-Hill USA; 2010.

[6] Holilah. Kawin Kontrak in Madura Society: Case Study of Causes and Its influences upon Relatives in Bumianyar, Tanjungbumi, Bangkalan. Jurnal penelitian. Surabaya: Univesitas Airlangga; 2005.

[7] Hurlock, E. B. Psikologi Perkembangan : suatu Pendekatan Sepanjang Rentang kehidupan (terjemahan: Istiwidayati). Jakarta: Erlangga; 2000.

[8] Jandt, F. E. Intercultural communication: An introduction (third ed.). Thousand Oaks: Sage; 2001.

[9] Kantor Berita Common Ground (CGNews) www.commongroundnews.org.

[10] Kompas, Column Kita, June 14, 2008.

[11] Lerrigo, A. Dilema Pernikahan Campuran. Available FTP: http://www.

Mixedcouple.co/article/mod.Php?mod=publisherandop=viewarticlean dartid4. Tanggal akses 20 Agustus 2015. 2005.

[12] McDermott, J.F., \& Maretzki, T.W. Adjustment Intercultural Marriage. Honolulu : The University of Hawaii; 1977.

[13] Mulyana, Deddy dan Rakhmat, Jalaluddin. Komunikasi Antarbudaya. Bandung: Rosdakarya; 2001.

[14] Nurwijaya, Hartati. Perkawinan Antarbangsa : Love and Shock. Jakarta : Restu Agung; 2007.

[15] Papalia, D. E., Olds, S. W., \& Feldman, R. D. Human Development (Psikologi Perkembangan Edisi Kesepuluh). Jakarta: Kencana; 2008.

[16] Roediger, Henry L and Mark A. Wheeler. Hypermnesia in Episodic and Semantic Memory: Response to Bahrick and Hall. Jurnal Psychological Science, Vol. 4, No. 3 (May, 1993), pp. 207208Published by: Sage Publications, Inc. on behalf of the Association for Psychological Science. Stable URL: http://www.jstor.org/stable/40062540 
[17] Rogers, E. M., \& Steinfatt, T. M. Intercultural communication. Prospect Heights, IL: Waveland Press.; 1999.

[18] Samovar, Larry A. Communication between cultures. Belmont, CA Wadsworth/Cengage Learning - Wadsworth series in speech. 2010.

[19] Sears, D.O., Freedman, J. L., \& Peplau, L.A. Psikologi Sosial. Terjemahan M. Adiyanto \& S. Soekresno. Jakarta: Airlangga; 1991.

[20] Simanjutak, B. Pengantar Psikologi Perkembangan. Bandung: Tarsito; 1990.

[21] Tseng, W.S., Mc Demott, J. F., \& Maretzki, T. W. Adjusment in intercultural marriage. Honolulu: The University Press of Hawaii; 1977. 